\title{
IAMJ
}

INTERNATIONAL

AYURVEDIC

MEDICAL JOURNAL

Research Article

ISSN: 2320-5091

Impact Factor: 6.719

\section{ADD ON EFFECT OF GRÑJANAKA PĒYA ALONG WITH A THERAPEUTIC DIETARY PROTOCOL IN RAKTĀRŚAH (BLEEDING PILE) - A NON-RANDOMIZED CONTROLLED TRIAL}

\author{
Bindu K.T ${ }^{1}$, M. C. Shobhana 2 , P. E Prema ${ }^{3}$ \\ ${ }^{1}$ Post Graduate scholar, ${ }^{2}$ Professor and HOD Department of Swasthavritta, ${ }^{3}$ Professor and HOD Department of \\ Shalyatantra, V P S V Ayurveda college Kottakkal, Edarikode (P O),Malappuram (Dt),Kerala.676501
}

Corresponding Author: dr.bindhushaji@gmail.com

https://doi.org/10.46607/iamj1 109072021

(Published Online: July 2021)

Open Access

(C) International Ayurvedic Medical Journal, India 2021

Article Received: 30/06//2021 - Peer Reviewed: 04/07/2021 - Accepted for Publication: 05/07/2021

Check for updates

\begin{abstract}
A non-randomized controlled trial was carried out in 40 participants with intervention for 15 days and a follow up of 7 days. Clinical signs and symptoms of raktārśah were assessed before and after the intervention and after following up, by using the subjective parameters scale including, Frequency of bleeding, Nature of bleeding, Change in colour of the mucosa of pile mass, Character of defecation and Period of straining. Grñjanaka peya along with a therapeutic protocol in raktārśa h has shown significant positive changes in subjective parameters like frequency of bleeding $(\mathrm{p}<0.01$ level), nature of bleeding $(\mathrm{p}<0.01$ level), changes in the mucosa, period of straining and character of defecation after the 15 days of intervention in the study group.
\end{abstract}

Keywords: Raktārśaḥ, Grñjanaka pēya, Therapeutic dietary protocol, Subjective parameters

\section{INTRODUCTION}

In the present era, people are inviting many health problems due to their food habits and lifestyles. Among them, Hemorrhoids are shooting one. Haemorrhoids are certainly one of the commonest ailments

that afflict mankind. It is dilated veins within the anal canal in the subepithelial region formed by radicals of the superior, middle and inferior rectal veins ${ }^{1}$.In Ayurveda Hemorrhoids are often compared with 
arśah. It is considered as mahāroga by Susrta and Vāgbhata It is an adhimāmsavikara formed at guda vali due to vitiated doṣas along with the vitiation of twak, mamsa and medas. It is classified in to 6 major types namely vatika, paittika, kaphaja, raktaja, sannipātaja and sahaja ${ }^{2}$. Other divisions are ardrarśah and sushkarśah. Bleeding is the major symptom of ardrarśah and it requires prior management. Bleeding is more profuse in first- and second-degree piles. Regular blood loss leads to weakness, anaemia and further complications. So the major concern of patients is to arrest bleeding. In classics, several factors are mentioned as nidāna for arśah such as ajeerna bhōjana, akala bhōjana, virudhasana etc. Haemorrhoids are inflamed and swollen veins around the anus and lower rectum, which usually occur as a result of altered dietary patterns, altered lifestyle, genetics and pregnancy. Arśah is a yāpya roga. So, it can be managed only by ouṣadha and ahära. Āhāra is mentioned as Mahābhaishajyam in Kāsyapa samhita 3. Pathya and apathya of arśah are mentioned in our classics. Management of arśah without following pathya is difficult. In the context of arśochikista Grñjanaka pēya is mentioned as raktapravāhajith ${ }^{4}$. Ácharya mentioned Grñjanaka is pathya in arśah. In common practice Grĩjanaka (swalpa nala palānduAllium ceppa $)^{5}$ is used to stop bleeding in bleeding piles. There are many home remedies for bleeding piles, which are incorporated with small onion ${ }^{6}$. Mode of administration of Grñjanaka through Peya. It is one of the preparations of Krutānna kalpana. It is laghu, pathya and having the properties such as vātanulomana, and agnideepana ${ }^{7}$. Pêyādi kalpana is the one which mentioned in almost all the classical texts indicated as pathyāhāra in different clinical conditions and for healthy people in various seasons, and as the dietary regulation after śódhana therapy. In conventional medicine, only symptomatic treatment is mentioned for arśah. Along with the proper treatment, the dietary principles in Ayurveda provides an added advantage. Ayurveda accepts āhāra as a drug and an important entity for treatment purposes. All the samhitās of Ayurveda emphasize the importance of diet in day to day life as well as in the prevention and treatment of diseases. Ayurveda has given much more importance to the rule of dietetics and this disease itself can be relieved by following the therapeutic diet. If people, follow pathyāhāra (wholesome diet) there will be no need of giving further medication; and if people do not follow the $p a$ thyāhāra the mere medication is in vein ${ }^{8}$. A therapeutic diet is the controlled and specific utilization of the food article as a beneficiary tool to tackle the diseased conditions ${ }^{9}$. Āhāra kalpanās (dietary pathyāhāra) is mentioned elaborately in the context of arśo chikitsa, but it is not yet explored significantly There are fewer numbers studies are available related to safe and cost-effective preparation such as peya and pathyāahāra in bleeding pile(Raktarśah). So, this trial is to assess the effect of Grĩjanaka peya along with therapeutic dietary protocol in the subjective parameters of bleeding pile (Raktarśah) such as frequency of bleeding, nature of bleeding, the character of defecation etc.

\section{Materials and Methods}

2.1 Trial Design: This study was a Non-Randomized open clinical trial, as these are more accurate for determining the efficacy in the initial step of new preparation. Ethical clearance was obtained for the study from the institutional ethics committee of V.P.S.V. Ayurveda College, Kottakkal. Approval no (IEC/CL/20/16) dated 28/04/2016) and amended on 04/05/2018.

2.2 Study Participants: Eligible participants satisfying inclusion criteria were screened from those who are coming in Salyatantra OPD at Ayurveda College Hospital. Among the screened participants 40 participants satisfying inclusion criteria and willing to give informed written consent were included in the study. Exclusion criteria were third and fourth-degree haemorrhoids, Bleeding per rectum other than haemorrhoids (such as gastric ulcer, rectal injury, IBS etc.)Patients undergoing anticoagulant therapy. Major systemic illnesses like uncontrolled hyperglycemia and uncontrolled hypercholesterolemia.Pregnant and lactating women.

\subsection{Intervention: Preparation of Grinjanaka pēya}


$15 \mathrm{gm}$ broken rice cooked with $210 \mathrm{ml}$ of water and processed with crushed onion, surasa leaves \& yamaka snēha ${ }^{10}$. Intervention gave for the selected participants Grĩjanaka pēya and Dietary intervention. The dose was $100 \mathrm{ml}$ and the time of intervention was between 11 am and $5 \mathrm{pm}$. Written diet chart with pathyās \& apathyās given to the Participants along with daily assessment chart. Properties of Grñjanaka peya mentioned in table 1.

2.4 Outcomes: Most of the signs and symptoms of the disease described in Ayurvedic classics are subjective. Hence, to provide some objectivity to the subjective results and to make easy the statistical analysis, the multidimensional scoring system was adopted for the patients. The assessment of the effect of the intervention was done based on the relief in the clinical signs and symptoms of arśah using Bleeding pile (Raktārśah)-Subjective parameter Clinical assessment Scale. This symptoms score was calculated before, after the intervention and follow up, The parameters were assessed before intervention $\left(0^{\text {th }}\right.$ day), $15^{\text {th }}$ day, $21^{\text {st }}$ day and after follow up.

2.5 Sample size: Sample size was calculated by the formula - $(Z \alpha+Z \beta)^{2}\left(\mathrm{p}_{1} \mathrm{q}_{1}\right)+\left(\mathrm{p}_{2} \mathrm{q}_{2}\right) / \mathrm{d}^{2}$ Prevalences of. $60 \%, 70 \%$ and Precision-15. Considering dropouts sample size was fixed to 40 (cases 20, controls 20). Among the screened participants 40 participants were satisfying the inclusion and exclusion criteria were selected for the study.

2.6 Statistical Analysis: Data was checked, analyzed and presented with the help of tables, graphs. Normality of data was tested by Q-Q plot in SPSS version 16. Repeated measures ANOVA was done to assess the effect of intervention between assessments. Bonferroni multiple comparisons test was used for pairwise comparisons. A Paired t-test was used to assess the effect of intervention between the groups. Statistical analysis was done by using Microsoft Office 2013 Excel and IBM SPSS Statistics version 16.

\section{RESULT}

3.1 Study population: Sixty-two participants within the age group twenty to sixty years were screened for assessing eligibility. Twelve met exclusion criteria. Among fifty eligible, forty participants were selected.
Those who were satisfying inclusion criteria and those who were willing to give informed written consent were included. From those 20 participants conveniently allocated in to study and control group; no drop out were observed (Figure Flow Diagram of participants)

3.1.1Baseline data: Participants were in the age group 20 to 60 years of having a male and female ratio in the percentage of study group 55:60 and control group 45:40. In dietary habits, $65 \%$ of participants in the study and control group were following mixed dietary pattern. $30 \%$ in the case and $20 \%$ in the control group were following a non-vegetarian diet and only $5 \%$ in the case and $15 \%$ in the control group were vegetarian. Distribution according to dietary habits are described in table2

3.2 Effect analysis: The subjective parameters such as frequency of bleeding, nature of bleeding, change in the mucosa, the character of defecation and period of straining were analyzed in both study and control groups. The first two was statistically significant at the level of $p<0.01$. Change in mucosa and Character of defecation were clinically significant but statistically insignificant. The parameter period of straining was showed statistically significant at the level of $\mathrm{p}<0.01$. As an objective parameter, Haemoglobin level in the blood was analyzed before and after therapy in both groups. In the study group, 5.76\% increase was noted but in the control group, only .77\% was increased. Mean values of assessments in case group and control group on subjective parameters mentioned in the table3

3.3 Adverse events: During intervention or the follow-up period, any adverse events or complications were not reported. After the completion of the study, those participants who need further treatment or follow up were directed to the ARC Clinic of the VPSV Ayurveda College Hospital.

\section{DISCUSSION}

Diet has a major role in the management of arśa it was told by Dr Jasir Ahammed in his study and without the proper following of diet, no treatment will be effective in the case of $\operatorname{arsa}^{11}$. The present study was 
undertaken to evaluate the effect of Grinjanaka pēya which was given in the dose of $100 \mathrm{ml}$ morning 11 and evening 5 along with a therapeutic dietary protocol for 2 weeks in bleeding piles as an add on effect. This play is mentioned as rakta pravahajit, so it will help to arrest the bleeding, and it is indicated in raktarśạ and raktatisara also.It has madhura rasa,guru,snigdha guna madhura vipaka and raktastambana in action ${ }^{12}$. Grñjanaka (Allium ceppa) which is Conventionally used by the practitioners for the management of the raktarśah in bleeding piles. Jalokath in 2013 on Ayurvedic influences in home remedies, mentioned that onion(Allium ceppa) can be used as a home remedy in bleeding piles. ${ }^{13}$ In this peya yamaka sneha is used for bharjana purposes, which is also helpful for avoiding vāta kopana due to blood discharge. The mode of administration of Grñjanaka is through pēya. Pêya is laghuthara,vātanulomini,pathya which is very much essential for the patients who are having arśa ${ }^{14}$. Therapeutic dietary protocol which is suggested for the study group is based on the pathyas mentioned for arśah in classics and strictly restricted to intake of apathyas also. Diet chart which is recommended to take lots of vegetables which is having tikta predominant $\mathrm{ra}$ sa.Tikta rasa is indicated for raktarśah. More than this diet is fibre rich which in turn ensure normal digestion Perez-Miranda et al in 1996 mentioned that fibre addition should be ensured in patients who refuse invasive treatment ${ }^{15}$. While considering the participant's distribution according to bowel habits showed that $72.5 \%$ were having irregularity in their motion that is it may be constipated, loose no regular time etc.. this presentation was supported by the study conducted by Johanson $\mathrm{HO}$ et, al observed that irregular bowel is the leading factor for $\operatorname{ars} a h^{16}$

\section{CONCLUSION}

The present study entitled "Add on the effect of pey along with therapeutic Dietary Protocol in Raktārśh (Bleeding pile)-Non-Randomized controlled trial" was an attempt to find out the efficacy of a simple cost effective therapeutic dietary preparation along with dietary intervention. After an elaborate review of literature, clinical observation, analysis of the data and discussions, the following conclusions are evolved. peya along with a therapeutic dietary protocol has a statistically significant effect in subjective parameters like frequency of bleeding, nature of bleeding, change in the mucosa, character of defecation and period of straining of Raktārśh (bleeding pile) among 20-60 years of age group.

\section{ACKNOWLEDGEMENT}

This paper was prepared out of the research endeavour undertaken in partial fulfilment of the requirements for awarding the degree of Doctor of Medicine (Ay) of the Kerala University of Health Sciences, Thrissur to the first author. The work was carried out at the Department of Swasthavritta, Vaidyaratnam P.S. Varier Ayurveda College, Kottakkal. The authors thank the staff of any rectal clinic of Ayurveda College, Kottakkal. Statistical support was provided by Dr PB Benil, Professor, Dept of Agadatan-tra, Vaidyaratnam P.S. Varier Ayurveda College

\section{REFERENCES}

1. Somen Das.A Concise Textbook of Surgery.3rd Edtn.Kolkata: Dr.S. Das publication; 2001. Chapter 46, The rectum and anal canal; P.960

2. Murthy K.R Srikanta translater. Vagbhata's Ashtanga Hrdayam Varanasi: Chowkhambha Krishnadas Academy; 2009; Vol 2 p.67-68.7/8. (Krishnadas Ayurveda series)

3. Tewari P V editor. Kasyapa Samhita Khilasthanam of Vrddha Jivaka. (Tewari P V, comme, English). Varanasi: Chaukhambha Visvabharati;2008; p.468.4/5-6

4. Murthy K.R Srikanta translater. Ashtanga Samgraha of Vagbhata (Text, English Translation, Notes and Index) Varanasi: Chowkhambha Orientalia;2005; p.392.10/37.Jaikrishnadas Ayurveda series-79

5. Acharya J T Vaidya Caraka Samhita of Agnivesa with Ayurveda Dipika commentary by Cakrapanidatta Varanasi: Chowkhambha Surbharati Prakashan; 2008; p. 262.27/274. (Chawkhambha Ayurvijnan Granthamala34)

6. Ten Home remedies for piles that work (Internet) Pavitra Sampath;2010 updated 2015/8/28; cited 2018/5/24.Available from www. the healthsite.com

7. Acharya JT. Editor. Susruta Samhita of Susruta (Nibadhasangraha, Dalhana, Comme, Sanskrit). Varanasi: Chaukhambha Orientalia;2014: p.238.46/341. (Jaikrishnadas Ayurveda Series No.34)

8. Saxena Nirmal. Editor. Vaidya Jivana of Lolimbaraja. Varanasi: Krishnadas Academy; 2000.p.5 
9. Swaminathan M. Essentials of Food and Nutrition.2nd ed. Bangalore: The Bangalore Printing and Publishing Co. Ltd;1991;2: p.144-299.

10. Sharangadhara, Sharangadhara Samhitā, with the commentary of Adhamalla's Dipika and Kashiram's Gudharth-Dipika, Chaukhamba Orientalia, Varanasi, IV edition, 2000; Madhyama Khandam. 6/13-14. P. 180.

11. Dr Jasir Ahammed: Study on the effect of local application of Pootika kshara in the management of 2nd and 3rd-degree haemorrhoids (M D dissertation) Thrissur, Kerala University of Health Science,2012.

12. Chauhan Rajani, Km Ruby" Golden herbs used in piles treatment: A concise report" Int. J. Drug \&Res. 2012
13. Ten Home remedies for piles that work (Internet) Pavitra Sampath;2010 updated 2015/8/28; cited 2018/5/24. Available from www. the healthsite.com

14. Acharya JT. Editor. Susruta Samhita of Susruta (Nibadhasangraha, Dalhana, Comme, Sanskrit). Varanasi: Chaukhambha Orientalia;2014: p.238.46/341. (Jaikrishnadas Ayurveda Series No.34)

15. Mirande et al, A study on the effect of fibre supplement in internal bleeding haemorrhoids, Pubmed medical journals 1996

16. Johanson JF, et al. A case-control study of potential etiological agents; Case-control study. The Am J Gastroenterology 1994; 89:198-200

\section{Table 1}

\begin{tabular}{|c|c|c|c|c|c|c|c|}
\hline Name & Rasa & Guna & Virya & Vipaka & Doșaghnata & \multicolumn{2}{|l|}{ Karma } \\
\hline Grõjanaka $^{91}$ & $\begin{array}{l}\text { Madhura } \\
\text { Katu }\end{array}$ & $\begin{array}{l}\text { Guru } \\
\text { Snigdha } \\
\text { Teekshna }\end{array}$ & Ishatushna & Madhur & $\begin{array}{l}\text { Vatakaphahāra } \\
\text { Pittavārdhaka }\end{array}$ & \multicolumn{2}{|c|}{$\begin{array}{l}\text { Dipana, pachana, rochana' Anulomana } \\
\text { Raktastambana, balya, } \\
\text { Ojovārdhanam Chedanam, Kapha } \\
\text { nisārakam Nidrajananam } \\
\text { Chārdhi nigraham }\end{array}$} \\
\hline Surasa $^{92}$ & $\begin{array}{l}\text { Katu } \\
\text { Tikta }\end{array}$ & $\begin{array}{l}\text { Laghu } \\
\text { Snigdha } \\
\text { Teekshna }\end{array}$ & Ushna & & Katu & Kapha vataghna & $\begin{array}{l}\text { Janthughna } \\
\text { Vedanastapana } \\
\text { Sothahāra } \\
\text { Tvagdoșahāra }\end{array}$ \\
\hline
\end{tabular}

Table 2

\begin{tabular}{|l|l|l|l|l|l|l|}
\hline \multirow{2}{*}{ Dietary habit } & Case & Control & Total & \\
\cline { 2 - 7 } & Number & $\%$ & Number & $\%$ & Number & $\%$ \\
\hline Vegetarian & 1 & 5 & 3 & 15 & 4 & 10 \\
\hline Non-vegetarian & 6 & 30 & 4 & 20 & 10 & 25 \\
\hline Mixed & 13 & 65 & 13 & 65 & 26 & 65 \\
\hline
\end{tabular}

Table 3

\begin{tabular}{|l|l|l|}
\hline Subjective parameters & Mean differences & \\
\cline { 2 - 3 } & Case & Control \\
\hline Frequency of bleeding & 1.55 & 0.85 \\
\hline Nature of bleeding & 1.55 & 0.85 \\
\hline Change in mucosa & 0.85 & 0.8 \\
\hline Character of defecation & 1.1 & 0.4 \\
\hline Period of straining & 0.947 & 0.631 \\
\hline
\end{tabular}

\section{Source of Support: Nil Conflict of Interest: None Declared}

How to cite this URL: Bindu K.T et al: Add On Effect Of Grñjanaka Pēya Along With A Therapeutic Dietary Protocol In Raktārśah (Bleeding Pile) - A Non-Randomized Controlled Trial. International Ayurvedic Medical Journal \{online\} 2021 \{cited July 2021 \} Available from: http://www.iamj.in/posts/images/upload/1393_1397.pdf 